\title{
VITACULTURAL HORIZONS OF TOLERANCE CONCEPTUAL COGNITION
}

\section{Ольга Шаюк ВІТАКУЛЬТУРНІ ОБРІЇ СУТНІСНОГО ПІЗНАННЯ ТОЛЕРАНТНОСТІ}

Topicality of the problem. Today's realities clearly show that humanity has entered a new phase of its existence, characteristic features of which are the transition from aggressive selfassertion of separate states and nations to a balanced position formation in solving any problems of global development. Thus, principles of tolerant behavior must permeate all levels of human relations from interracial to interpersonal. However, the implementation of such transition is impossible by only conventional agreements and humane decisions. There is a grand work of forming new form of consciousness in front of the humanity, and therefore is actualized by the task of mechanisms analysis, that promote or hinder the formation of tolerance consciousness.

The state of the problem research. The topic of tolerance is actively discussed in various aspects: state-legal, ethic-philosophical, political-ideological, psychological-pedagogical, sociological, etc. However, this inconsistency causes a lot of difficulties and contradictions in its understanding: on the one hand, scientists agree that tolerance is a virtue, value of which is hard to argue, and on the other there are discussions about the tolerance both boundaries and limits. The disagreement is also perused in scientists' justification, assumptions, factors and action mechanisms of the complex covital phenomenon.

A significant contribution to the formation of the semantic field of the phenomenon of tolerance belongs to philosophers, which relate it to other phenomena and concepts, among which the most notable are the particular median soulful mood (Aristotle), social cohesion (Plato), the measure of agreement (Leibniz), toleration (John Locke), goodness (Kant), the identity and recognition of the equal value of all people (N. Berdyaev, etc.).The modern philosophical conceptions consider tolerance in line with the problems of liberalism, national identity and multiculturalism (M. Walzer). Within the philosophical concept of critical rationalism there were introduced the grounds to determine the limits of tolerance and the paradox of tolerance was formulated: unlimited tolerance must lead to the disappearance of tolerance (Karl Popper). But in psychology there are direct and indirect appeals to the concept of tolerance, proved patterns of development in situations of communication, social interactions, interpersonal and intergroup relations, social cognition, and group dynamics, conflicts, value orientations, group norms, motivation, organizational culture, management, mass and global processes during social and cultural adaptation, innovative transformations and social reforms.

Concepts and definitions, which in the psychological literature are related with tolerance, are, also, very ambiguous and include different reflexive understandings of its conceptual content. So, different authors describe tolerance as: a) approving behavior, and rejection of the imposition of the views of one person to another, b) the adoption of the agreement on the "rules of the game", c) respect for other opinions, d) a certain quality of interaction, e) special intersubjective relations, f) reducing the sensitivity

Copyright @ ШАЮК Ольга Ярославівна, 2017. 
to the object, g) psychological stability, h) system of positive units, i) the set of individual qualities, $j$ ) system of personal and group values, $\mathrm{k}$ ) tolerance of the individual to any outside pressure or dictates, etc. Also, scientists are trying to describe differences of tolerance from such concepts and ideas like toleration, conformity, trust, kindness, mannerliness, generosity, decency, spirituality and so on.

The represented definition of tolerance clearly demonstrates that scientists are unable not only to give tolerance unequivocal definition to reduce its essence to a single performance, but also to localize a specific theme, and this means that tolerance requires a comprehensive analysis as a phenomenon-feature, and as a category of modern philosophical and scientific discourse.

The attempt of multi-disciplinary and interscientific solution to this problem was A.V. Furman's complex of tolerance research as a potential bases of a new state ideology in the center of which is the idea of Ukraine-creation [see 3]. This work presents a philosophical-methodological substantiation of the genesis of tolerance as a factor of sustainable social development and factor of social and cultural integration of Ukrainians in ontology-phenomenological, gnosiology-noumenological, psychosocial and psychosophical directions of his reflexive thinkactivity processing. The study argumented the productivity of development of psychosophical study of tolerance, researched tolerance as a way of human being and therefore vitacultural forms of its appearance in the life of humanity, nations, ethnic groups, organizations, groups and socialized individuals; implemented reflective thinkactivity processing of represented ontophenomenal givens in different contexts of ideological, scientific, social and psychospiritual realities [see 10].

Author's achievements in this sphere concern studying of tolerance as integral personality trait in a wide palette of its forms and individual psychological characteristics of the development; substantiation five-component structure of tolerance, as a well, its psychological characteristics of students of a certain specialization; empirical study of the psychological peculiarities of the formation and development of professional tolerance $[11 ; 12 ; 13 ; 14]$.

In course of this extremely important are new horizons of methodology of cognition of tolerance in the thematic format of vitacultural metaparadigm within which contently enriched and amplified are becoming ontological fundamentals through their implementation in conceptual and values cognition of the moral and practical circumstances of human existence and the cyclically integral human being in general. As a result it is possible to understand tolerance as a separate ontophenomenological given, and as a form of human life, and as a special psychospiritual state-property of human, and as ideological universal, and as a powerful theoretical construct of modern philosophical and scientific discourse.

The purpose of the research: on the basis of principles, orienting points, concepts and norms of vitacultural paradigm and methodological resources of VC-metodologization present new horizons of reflective thinking-active processing of tolerance.

Discussion. Vitacultural paradigm for the last twenty years has been developed by A. V. Furman and his experimental school in various theoretical and applied contexts - theoretical psychology [2; 4], psychoculture of the Ukrainian mentality [7], concept of professional metodologization $[4 ; 5]$, theory of educational activity $[8 ; 9]$, ontology of the game [6], etc. With powerful conceptually systematic tools, it is the methodological basis of many theoretical, methodological, project and empirical research. Today Anatoly Furman's vitacultural paradigm, which has arisen from rethinking and H.P. Shchedrovytskyi's reasoning system thinking-active methodology, is a competitive product in the field of socio-cultural knowledge. In particular, we assume there are grounds to believe that its semantic potential actualized by synthesis of scientific concepts and viability of culture, strengthened integrated scientific worldview concept - "the author's version of the methodology, full and complete part of modern science - vitacultural methodology, ie, methodology of the methodologies or "metametodology" which examines and reflects the logical organization and conceptual-categorical system, structure and dynamics of the methods and means of selforganizing and materialization of philosophical and scientific systems, public and private practices, as well as different levels of functioning of methodological knowledge in forms, acts and actions, means and tools of problem-modular think-activity to justify methodologies, techniques and application of knowledge, development, design and man's conversion of the world in the widest context of its relationship with the universe "[5, p. 159].

Obvious advantages of Professor A.V. Furman's school is that it broadens the horizons of 
knowledge, opens up rich in ideas, concepts, thinking schemes, models, methodological schemes scientific field to its members, thus diversifying the possibilities of self researcher's own reflective thinking activity, but with the need to clearly follow certain principles and canons of cognitive and social commission. We mean fundamental principles of methodological nature which A.V. Furman mentions as the implementation of secured intellectual and instrumental practice of professional methodologies. Of course, this poses the researcher a number of requirements, among which should be noted the urgency of continuous critical reflective dive as a topical discursive field, and a complex system of dominant paradigms, effectively intense use of social narratives of interpretational techniques, methods, techniques and tools in the way of understanding the essence and content of the studied phenomena (see in detail [5]).

In the previous study principles, guidelines, concepts and standards of the vitacultural paradigm were proved, allowing to highlight the nature and phenomenology of tolerance in five different segments (see [9]). Based on the materials of this study we will point out to the benefits of VC-methodologizing.

Firstly, the format of vita cultural paradigm in full-length manages to cover onto-phenomenal field of tolerance as a way of co-existence of people, groups, ethnic groups, nations, although it rather complicates the situation of cognition: blurred in everyday reality, markers of understanding, harmony, trust, tolerance illusory make an impression of its presence and importance in public life and situational eventfulness, while their integrity and identity are largely misleading self-respect, mundane urgency of human intentions and goals. And it is natural, because the positive and negative, personality signs-quality are always somehow mixed, dialectically linked. And the "total" tolerance is possible only in the ideal world with mature theoretical thinking.

Secondly, the combination of methodological resources of symbols, schematics, ways and means of interdependent knowledge-construction of vitality and culture as distinct and permeated areas of human social routine (see. [7]) allows not only to present tolerance as a separate ontophenomenon quality, but also to prove it as one of given forms of social life. This means that tolerance is the category which fixes one of the possible bases of the world existence both in general and any kind of organization or its essential duration.
Thirdly, the effects of one of the laws of mediation are confirmed: the established form, manner and style of human interaction and rich symbolic and cultural value space and are not related either directly or linear and clearly. Local and global measurements of vita cultural world, totally formatted by sociality, and updated and revived by natural integrator - psychics - known in its dimensions: self, group, societal and human. So naturally tolerance is also an important property in system of human daily life, a compulsory prerequisite of social trust and a crucial factor for understanding, harmony, peace, success and social harmony.

Fourthly, it has been reasonably and quite logically justified tolerance as not only important categorical social and human cognition of modern knowledge, but as a worldview universal of global scope vita culture. That can be proved by V.S. Stopin's philosophical generalizations "ideological boundary universals are ascending concepts that "in cooperation and conjunction set generalized image of the human world, focus "historically accumulated social experience, can be arranged as "a kind of deep program social life of groups, ethnic groups, and people" $[\mathbf{1}, \mathbf{p}$. 19, 20], totally permeate all societal processes, states, and properties. Obviously the category of "tolerance" refers to the second unit of culture universals that determine a man as a human subject, personality-life activities, personality, his commitment and his relationship to other people and society in general, the goals and values of the social life. Therefore, in communion with other categories it combines historically accumulated positive human personal experience from ontogeny to the system of social relations and communication. As universality, tolerance has its own unique invariant, abstract general meaning inherent in different types of cultures (selfrespect - trust - tolerance - respect mutual help), and the original, which describes the underlying structure of the ethnic mentality and societal psyche. In any case, a thorough understanding of tolerance architectonics significantly enriches and optimizes the outlook of the modern era.

Fifthly, the VC-methodologizing allows and profiles another segment: tolerance is a powerful theoretical construct of the modern philosophical and scientific discourse, as evidenced by the fact that: a) "tolerance" as a categorical concept and a universal of culture includes multidimensional semantic content in the disassociation of specific linguistic forms of expression of the term and 
1 - ontophenomenological: interprets tolerance as sociopsychological and cultural phenomenon, that is, as ontophenomenological reality of everyday social life, as actuality of the modern world and as human being, which is characterized by many of positive existential moments and phenomenal features, among which attributive are toleration, mutual respect, understanding, trust, guilt culture, tact, loyalty and others.
4 - psychosophical: describes tolerance as psyhosophical organization of problemmodular thinking-activity, and therefore as a category of culture or worldview universal that correlates mental and language, emotional and intellectual, irrational and rational, archetypal and clearly understood, existential and moral components of the historical experience of the nation, ideologically programs the life of the individual and society, enriches the mass consciousness with beliefs about acceptable forms, methods and means of social behaviors, situational interaction and understanding.
2 - gnosiology-noumenological: considers tolerance as an important concept of modern philosophical and theoretical understanding and professional metodologization, and which is based on intellectual resources of ontological views on the reality and present it as gnosiology-noumenological reality that makes possible understanding and acceptance of complexity of life reality, and variability of its perception, understanding and appreciation of different people, and of relativity, incompleteness and subjectivity of own perceptions and own world picture.
3 - psychosocial: defines tolerance as a psychological and social givens, and thus as an integral feature-quality of personality, which determines its active position in relation with people regardless of their cultural, social and national identity, ensures openness and readiness for dialogue, and essentially respects the other, presupposes understanding under any conditions, including conflicts, and neutralizes internal aggressiveness and intransigence within personality and the group, collective, ethnic group, and nation.

Figure

Pbilosopbical and methodological directions of substantiation of tolerance ( see in detail $[3 ; 10]$ )

its synonyms in ("tolerance," "endurance", "politeness", "compliance", "appeasement" and others.) b) the concept of "tolerance" acts as a systematizing philosophical basis and psychosocial concepts which are characterized by ontological background; c) structuring and systematizing around a specific set of concepts, this construct leads to the formation of a conceptual scheme, which operates in a mode of understanding-explanation and in its entirety enables ways of observing and constructing psychosocial reality.

However, organizing and explaining vita cultural way of tolerance cognition gives thinking scheme of systematically and hierarchically connected methodological research areas of the indicated phenomenon (figure). This interconnected contents allows reflexive grasp tolerance as a socio-psychic and cultural phenomenon and as an important concept of modern philosophical 
thinking and professional methodologies and as integrated personality trait-quality which is characterized by respect and tolerance for the other, different or alternative involves understanding and reconciling the interests and coordination of interests under any circumstances, the harmony of different motives, orientations and ideas without force, and as a category of culture or worldview universal, which enriches the mass consciousness with beliefs about acceptable forms, methods, means of social and interpersonal commitments, and therefore ideologically programs life of every citizen (see [10]).

Thus, heuretic of vitacultural paradigm in general, and in this format of methodologizing in particular, is that it integrates the achievements of other dominant paradigms that not only tolerate individual requirements, values, methods and techniques of studying tolerance essence and phenomenology of the known theoretical models into the realm of its own philosophical and / or psychosocial content, but also adds the findings and implications of different concepts and theories to explain, predict and design new and little-known structures of thinking and empirical data regarding the genesis, premises, factors, shapes, methods, tools, parameters, characteristics and features of tolerance in its various ontophenomenon dimensions personal and collective, and psycho-spiritual and social, existential and rational, spontaneous and value-semantic.

\section{THE LIST OF USED LITERATURE}

1. Стьопін В.С. Культура / В'ячеслав Стьопін // Психологія і суспільство. - 2015. -№1. - С. 16-25.

2. Фурман A.B. Вітакультурнеобгрунтування практичної психології / А.В. Фурман // Практична психологія і соціальна робота / гол. редактор О.В. Губенко. - 2003. - №4. - С. 9-13.

3. Фурман A.B. Генеза толерантності та перспективи українотворення (комплексний проект) / А.В. Фурман // Психологія і суспільство. - 2013. - №1. - С. 6-20.

4. Фурман А.В. Ідея і зміст професійного методологування: [монографія] / Анатолій Васильович Фурман. - Тернопіль: ТНЕУ, 2016. - 378 с.

5. Фурман A.B. Ідея професійного методологування [монографія] / Анатолій Васильович Фурман. - ЯлтаТернопіль: Економічна думка, 2008. - 207 с.

6. Фурман А.В. Психокультура української ментальності: [наук. вид.] / Анатолій Васильович Фурман. - Тернопіль: НДІ МЕВО ТНЕУ, 2010. - 168 с.

7. Фурман A.B. Теорія освітньої діяльності як метасистема / Анатолій В. Фурман // Психологія і суспільство. - 2002.- №3-4. - С. 20-58.

8. Фурман A.B. Теорія освітньої діяльності: концепти і фундаменталії : [монографія] / Анатолій Васильович
Фурман. - Тернопіль : Економічна думка, 2010. - 392 c. - Репринт.

9. Фурман A.B., Шандрук С.К. Організаційнодіяльнісні ігри у вищій школі: [монографія]/ Анатолій В. Фурман, Сергій Шандрук - Тернопіль: ТНЕУ, 2014. $-272 \mathrm{c}$.

10. Фурман А.В., Шаюк О.Я. Толерантність як предмет онтофеноменологічного дискурсу / А.В. Фурман, О.Я. Шаюк // Психологія і суспільство. - 2015. № 3. - С. 31-61

11. Шаюк О.Я. Особливості психологічної структури толерантності майбутніх економістів / О.Я. Шаюк // Психологія і суспільство. - 2011. - № 3. - С. 28-65.

12. Шаюк О.Я. Особливості формування емоційновольового компоненента толерантності у майбутніх економістів / О.Я. Шаюк // Психологія і суспільство. 2013. - № 3. - C. 126-130.

13. Шаюк О.Я. Особливості формування поведінкового компонента толерантності у майбутніх економістів / О.Я. Шаюк // Психологія і суспільство. - 2013. - № 4. - С. 143-146.

14. Шаюк О.Я. Психологічні особливості формування професійної толерантності у майбутніх економістів: дис. на здобуття вчен. ступеня канд. психол. наук: спец. 19.00.07 "Педагогічна та вікова психологія" / Ольга Ярославівна Шаюк. - Хмельницький, 2012. - 215 с.

\section{REFERENCES}

1. Stopin V.S. Kultura / ViacheslavStopin // Psykholohiia i suspilstvo. - 2015. -№1. - S. 16-25 [In Ukrainian].

2. Furman A.V. Vitakulturne obhruntuvannia praktychnoi psykholohii / A.V. Furman // Praktychna psykholohiia i sotsialnarobota / hol. redaktor O.V. Hubenko. - 2003. - №4. - S. 9-13 [In Ukrainian].

3. Furman A.V. Geneza tolerantnosti ta perspektyvy ukrainotvorennia (kompleksnyiproekt) / A.V. Furman // Psykholohiia i suspilstvo. - 2013. - №1. - S. 6-20 [In Ukrainian].

4. Furman A.V. Ideia i zmist profesiinoho metodolohuvannia: [monohrafiia] / Anatolii Vasylovych Furman. - Ternopil: TNEU, 2016. - 378 s. [In Ukrainian].

5. Furman A.V. Ideiaprofesiinohometodolohuvannia [monohrafiia] / AnatoliiVasylovychFurman. - YaltaTernopil: Ekonomichn adumka, 2008. - 207 s. [In Ukrainian].

6. Furman A.V. Psykhokulturaukrainskoimentalnosti: [nauk. vyd.] / AnatoliiVasylovychFurman. - Ternopil : NDI MEVO TNEU, 2010. - 168 s. [In Ukrainian].

7. Furman A.V. Teoriia osvitnoi diialnosti yak metasystema / Anatolii V. Furman // Psykholohiia i suspilstvo. - 2002.- №3-4. - S. 20-58 [In Ukrainian].

8. Furman A.V. Teoriia osvitnoi diialnosti: kontsepty i fundamentalii : [monohrafiia] / Anatolii Vasylovych Furman. - Ternopil: Ekonomichna dumka, 2010.-392 s. - Reprynt [In Ukrainian].

9. Furman A.V., Shandruk S.K. Orhanizatsiinodiialnisni ihry u vyshchiishkoli: [monohrafiia] / Anatolii V. Furman, Serhii Shandruk - Ternopil: TNEU, 2014. 272 s. [In Ukrainian].

10. Furman A.V., Shaiuk O.Y. Tolerantnist yak predmet ontofenomenolohichnoho dyskursu / A.V. 
Furman, O.Y.Shaiuk // Psykholohiia i suspilstvo. - 2015. - № 3. - S. 31-61 [In Ukrainian].

11. Shaiuk O.Y. Osoblyvosti psykholohichnoi struktury tolerantnosti maibutnikh ekonomistiv / O.Y. Shaiuk // Psykholohiia i suspilstvo. - 2011. - № 3. - S. 28-65 [In Ukrainian].

12. Shaiuk O.Y. Osoblyvosti formuvannia emotsiinovolovoho komponenenta tolerantnosti u maibutnikh ekonomistiv / O.Y. Shaiuk // Psykholohiia i suspilstvo. 2013. - № 3. - S. 126-130 [In Ukrainian].

13. Shaiuk O.Y. Osoblyvosti formuvannia povedinkovoho komponenta tolerantnosti u maibutnikh ekonomistiv / O.Y.Shaiuk // Psykholohiia i suspilstvo. 2013. - № 4. - S. 143-146 [In Ukrainian].

14. Shaiuk O.Y. Psykholohichni osoblyvosti formuvannia profesiinoi tolerantnosti u maibutnikh ekonomistiv: dys. nazdobuttiavchen. stupeniakand. psykhol. nauk: spets. 19.00.07 "Pedahohichna ta vikova psykholohiia" / Olha Yaroslavivna Shaiuk. - Khmelnytskyi, 2012. - 215 s. [In Ukrainian].

\section{АНОТАЦІя}

\section{Шаюк Ольга Ярославівна.}

Вітакультурні обрії сутнісного пізнання толерантності.

В статті окреслено новітні обрії методології пізнання толерантності в тематичному форматі вітакультурної парадигматики; на основі принципів, орієнтирів, концептів і нормативів зазначеної метапарадигми та методологічних ресурсів ВК-методологування презентовано сутнісно збагачене осмислення толерантності як окремої онтофеноменальної даності, форми людського буття, особливого психодуховного стану-властивості людини, світоглядної універсалії і потужного теоретичного конструкту сучасного філософсько-наукового дискурсу; в аналітичних рамках окресленого теоретико-методологічного рефлексування підтверджено іiі як усталений спосіб конструктивного співжиття людей, груп, етносів, націй, як засадничу цінність сучасної культури, як усвідомлену, осмислену і відповідальну життєву позицію, реалізація якої в кожній окремій ситуації має певний смисл і вимагає від толерантної особистості благодатного пошуку смислу та прийняття нею людського світу як рівноправного суб'єкта.

Ключові слова: толерантність, людина, світ, суспільство, буття, вітакультурна парадигма, світ вітакультури, онтофеноменальна даність, психодуховний станвластивість, світоглядна універсалія, теоретичний конструкт, філософсько-науковий дискурс, співіснування, подолання, терпимість, безконфліктність, визнання за іншими права на володіння істиною, активна позиція, основа для духовного зростання, моральний принцип, взаємоповага, співпраця, неагресивне протиставлення, суперечність, прийнята відмінність.

\section{АННОТАЦИЯ}

\section{Шаюк Ольга Ярославовна.}

Витакультурные горизонты сущностного познания толерантности.

В статье очерчены новейшие горизонты методологии познания толерантности в тематическом формате витакультурной парадигматики; на основе принципов, ориентиров, концептов и нормативов отмеченной метапарадигмы и методологических ресурсов ВКметодологизирования осуществлено обогащенное осмысление толерантности как отдельной онтофеноменальной данности, формы человеческого бытия, особенного психодуховного состояния-свойства человека, мировоззренческой универсалии и мощного теоретического конструкта современного философсконаучного дискурса; в аналитических рамках очерченного теоретико-методологического рефлексирования толерантность подтверждена как установившийся способ конструктивного сожительства людей, групп, этносов, наций, как основоположная ценность современной культуры, как осознанная, осмысленная и ответственная жизненная позиция, реализация которой в каждой отдельной ситуации имеет определенный смысл и требует от толерантной личности благостного поиска смысла и принятия ею человеческого мира как равноправного субъекта.

Ключевые слова: толерантность, человек, мир, общество, бытие, витакультурная парадигма, мир витакультуры, онтофеноменальная данность, психодуховное состояние-свойство, мировоззренческая универсалия, теоретический конструкт, философсконаучный дискурс, сосуществование, преодоление, терпимость, бесконфликтность, признания за другими права на владение истиной, активная позиция, основа для духовного роста, моральный принцип, взаимоуважение, сотрудничество, неагрессивное противопоставление, противоречие, принятое отличие.

\section{ANNOTATION}

\section{Shayuk Olha.}

Vitacultural horizons of tolerance conceptual cognition.

The article outlines newest horizons of methodology of cognition the tolerance in thematic format of vita-cultural paradigmatic; on the base of principles, guidelines, concepts and standards of indicated meta-paradigm and methodological resources of VC-methodologization presented essentially enriched understanding of tolerance as a separate onto-phenomenal givens, form of human existence, special psycho-spiritual state-property of the human, worldview universals and powerful theoretical construct of modern philosophical-scientific discourse; in analytical frameworks of outlined theoretical-methodological reflexion is confirmed it as the established way of constructive co-existence of people, groups, ethnic groups, nations as a basic value of modern culture, as a conscious, comprehended and responsible life position, realization of which in each separate situation has certain meaning and requires from tolerant personality of grace search the meaning and acceptance by it the human world as equal subject.

Keywords: tolerance, human, the world, society, being, vitacultural paradigm, the world of vitaculture, ontophenomenal givens, psycho-spiritual state-property, worldview universals, theoretical construct, philosophical-scientific discourse, coexistence, overcoming, toleration, withoutconflictness, the recognition by other the right for possession the truth, active position, the basis for spiritual growth, moral principle, mutual respect, cooperation, non-aggressive opposition, contradiction, accepted difference.

Надійшла до редакції 22.02.2017. 